\title{
THE ANNUAL GROWTH AND REPRODUCTIVE CYCLE OF THE ASCIDIAN DENDRODOA GROSSULARIA (VAN BENEDEN)
}

\author{
By R. H. Millar \\ Marine Biological Station, Millport
}

(Text-figs. I-II)

This paper is the second of a series dealing with the annual cycle of growth and reproduction in British ascidians; a previous paper (Millar, I952) dealt with the species Diplosoma listerianum (Milne Edwards), Ciona intestinalis (Linnaeus), Ascidiella aspersa (Müller), and Botryllus schlosseri (Pallas).

The present investigation is concerned with the growth, the course of sexual reproduction and establishment of new generations, and the histological changes in the gonad throughout the year, in the ascidian Dendrodoa grossularia (family Styelidae).

Samples were examined from two widely separated localities: Fambridge in the River Crouch, Essex; and Farland Point, Isle of Cumbrae, in the Firth of Clyde. The specimens from Essex were dredged from a depth of about $2 \mathrm{~m}$. (below L.W.O.S.T.), and were attached to the empty shells of the European oyster, Ostrea edulis L. and to the shells of Crepidula fornicata L. The specimens from the Firth of Clyde were attached to stones on sheltered parts of the shore. The animals here extended over a zone of the shore from about Chart Datum $+2.5 \mathrm{ft}$. $(0.76 \mathrm{~m}$.) to about Chart Datum $+7.5 \mathrm{ft}$. $(2 \cdot 29 \mathrm{~m}$.) . Only in very sheltered positions, such as under large boulders, did Dendrodoa occur in abundance. The two habitats were thus very different in nature, one being sublittoral on the south-east coast of Britain and the other being littoral on the north-west coast. The value of comparisons is limited by the different nature of the conditions to which the sublittoral and the littoral populations were exposed.

The observations on growth in the Clyde extended over most of I95I and I952, and nineteen samples were taken. The ten samples in 1952 were used for examination of breeding condition, and of histological state of the gonad. Eleven samples from Essex covered the period December I95I-December I952, and supplied data on growth, breeding condition, and histological state of the gonad.

I wish to thank Mr M. N. Mistakidis and Mr G. Duncan Waugh, of the Ministry of Agriculture and Fisheries, for collecting and sending the samples from Essex, and for providing temperature records for that area. 


\section{GROWTH}

About 200 animals in each sample were measured, to the nearest $0.1 \mathrm{~mm}$., the antero-posterior length of the body being taken as a measure of the size. Care was taken to measure the length of the body itself, excluding the basal expansion of test which is very variable in extent. The length of the body is not an entirely satisfactory measure of the size since the ratio of length to height varies to some extent with the habitat, but length was found to be the best practical measure available.

\section{The Essex population}

Histograms of the distribution by size of $D$. grossularia in the samples from Essex during 1952 are shown in Fig. I. The samples of I 5 December I95I and I5 January 1952 represent the winter state of the population. There are two clearly separable components: (i) individuals up to about $\mathrm{I} .5 \mathrm{~mm}$. long, and (ii) the remaining individuals from about $1.5 \mathrm{~mm}$. to about $8.5 \mathrm{~mm}$. in length.

There is no clear indication of spring growth until after 25 March I952, although it may have started somewhat earlier than this. Considerable growth occurred in the animals of the 0-1.5 mm. group, between late March and early May, and continued throughout June and July so that they had attained a length of $4.0-5.5 \mathrm{~mm}$. by 22 July 1952 . No significant change is seen in the form of the histograms, for sizes over $4.0 \mathrm{~mm}$, in the period up to 22 July 1952 . This is due to the growth of small animals up into the size groups over $4.0 \mathrm{~mm}$. and, we may suppose, little growth in the large animals together with death of the oldest ones.

During May and to a less extent in April and June the spring settlement of I952 took place. This period of settlement is confirmed by the presence of larvae in breeding individuals (see pp. $3^{8-40}$ ). Little or no settlement took place in August.

The autumn settlement occurred mainly in September, October and November, and these animals attained a length of up to $1.5 \mathrm{~mm}$. before growth stopped for the winter. The histogram of 5 December 1952 again shows the winter structure of the population, with two components: (i) individuals under $\mathrm{I} \cdot 5 \mathrm{~mm}$. representing the autumn 1952 settlement, and (ii) individuals from about $\mathrm{I} .5 \mathrm{~mm}$. up to the maximum size, representing the spring 1952 settlement together with an unknown proportion of the I95I settlements.

During a considerable part of the year, from the time of establishment of the autumn generation through the winter and on into the spring there are present at least three groups of individuals of separate origin. Thus in the autumn of the year $n$ these groups represent (i) the autumn settlement of the year $n$, (ii) the spring settlement of the year $n$, and (iii) the autumn settlement of the year $n-\mathrm{I}$, together with some unknown proportion of the settlements of spring $n-\mathrm{I}$, and of the year $n-2$. 

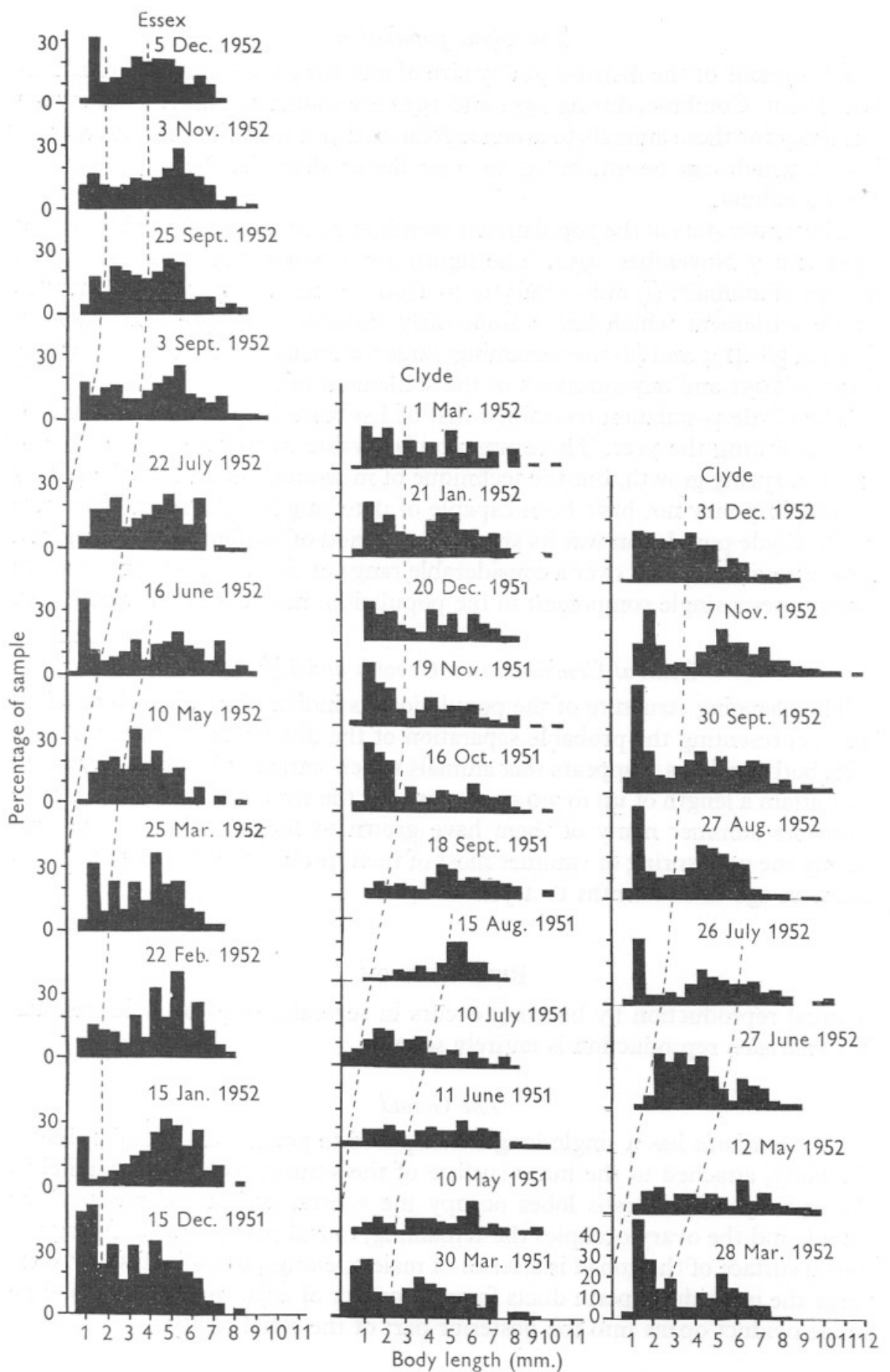

Fig. I. Size-frequency histograms of $D$. grossularia samples from Essex and the Clyde. 


\section{The Clyde population}

Histograms of the distribution by size of animals in the samples from Farland Point, Cumbrae, during I95I and 1952 are shown in Fig. I. There was a tendency for these animals to attain a greater length than the specimens from Essex, which can be attributed to their flatter shape in the more exposed littoral habitat.

The winter state of the population is seen in the histograms for 20 December 195I and 7 November 1952. The figure for 7 November 1952 shows two groups of animals: (i) individuals up to about $3.5 \mathrm{~mm}$. long, representing the single settlement which lasted from early summer until late autumn I952 (see pp. 38-4I); and (ii) the remaining, larger, animals representing the settlement of I95I and any survivors of the settlement of 1950 .

The Clyde population resembled that of Essex in the period and extent of growth during the year. There was no observable difference in the time of onset of spring growth, but the technique of measurement and the frequency of sampling may not have been capable of detecting it. The main difference in the Clyde population was its single long period of settlement resulting in a new generation spread over a considerable range of sizes. Each year therefore contributes a single component to the population, instead of two as in Essex.

\section{General Conclusions on Growth and Life Span}

The changing structure of the populations is indicated in Fig. I by broken lines representing the probable separation of the different components.

In both localities it appears that animals which settled as larvae in any given year attain a length of up to 3.0 or $3.5 \mathrm{~mm}$. by the winter of that year. By the following summer many of them have grown to their maximum size, and during the next spring or summer most of them probably die. They may thus attain an age of 18 months to 2 years.

\section{REPRODUCTION}

Asexual reproduction by budding occurs in several groups of ascidians, but in Dendrodoa reproduction is entirely sexual.

\section{The Gonad}

D. grossularia has a single long hermaphrodite gonad on the right side of the body, attached to the inner surface of the ventral body wall, parallel to the endostyle. The testis lobes occupy the ventral and lateral parts of the gonad, and the ovary occupies the remaining, dorsal part (Fig. 6). Along the dorsal surface of the gonad is a series of male openings, to each of which converge the individual sperm ducts from a number of adjacent testis lobes. The single oviduct opens into the posterior part of the atrial cavity. 


\section{Brood Filaments and the Retention of Developing Eggs}

When the eggs are extruded from the oviduct they are not carried away by the exhalent stream of water out through the atrial siphon. Instead they are retained within the atrial cavity by a group of specially developed filaments which do not seem to have been described and which may be called the brood filaments. These filaments, which are numerous and closely spaced, stretch across the atrial cavity from the outer surface of the posterior part of the branchial sac to the inner surface of the body wall opposite (Fig. 2). They are

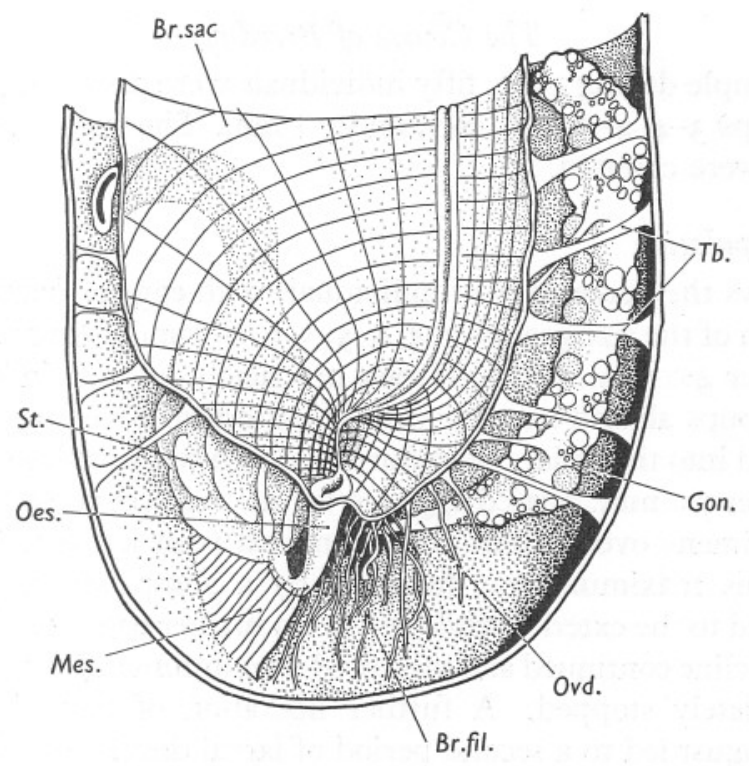

Fig. 2. Ventral half of the posterior part of the body of D. grossularia. $B r$. sac, branchial sac; Br.fil., brood filaments; Gon., gonad; Mes., mesentery; Oes., oesophagus; Ovd., oviduct; St., stomach; $T b$., trabeculae.

probably homologous with the trabeculae which pass from the branchial sac to the body wall in other parts of the body, and which maintain the branchial $\mathrm{sac}$ in position. Since the opening of the oviduct lies immediately ventral to this mass of brood filaments, the eggs as they are shed become entangled amongst the filaments. Here they are fertilized and remain during subsequent development to the larval stage. The larvae, however, when fully developed tend to become free of the brood filaments and to spread into the adjacent part of the atrial cavity, on the right. Eggs and larvae are prevented from passing into the left part of the atrial cavity by a vertical mesentery uniting the body wall to the oesophagus, stomach and posterior end of the branchial sac. The liberation of the larvae from the entangling brood filaments may be due both to muscular movements of the larvae and to the pressure of increasing numbers of eggs shed from the oviduct. When thus freed from the 
brood filaments the larvae can be carried by the exhalent current to the exterior. The mechanism ensures that it is the most advanced larvae, that is those developed from eggs first shed from the ovary, that are freed from the brood filaments to pass to the exterior, while the younger developing eggs are still retained.

The brood filaments are often found to be attached only at one end, usually to the outer wall of the branchial sac, a condition resulting from their being broken by the pressure of large numbers of eggs.

\section{The Course of Breeding}

In each sample during 1952, fifty individuals were dissected, ten in each of the size groups $3-4,4-5,5-6,6-7$, and $7+\mathrm{mm}$. The eggs and larvae in the atrial cavity were counted.

\section{The Essex Population}

Fig. 3 shows the percentage of individuals with eggs or larvae in the atrial cavity, in each of the size groups $3-4,4-5,5-6,6-7$ and $7+$ mm., during 1952 . Animals under $4.0 \mathrm{~mm}$. in length took practically no part in breeding. The remaining groups all had a rather similar pattern of breeding activity. Eggs were first shed into the atrial cavity during March when, although $30 \%$ of the specimens over $7.0 \mathrm{~mm}$. carried eggs, no larvae were yet present. On Io May I952 all specimens over $6 \mathrm{~mm}$., and many between 4.0 and $6.0 \mathrm{~mm}$., were breeding. This maximum was followed by a sharp decline, many larvae having escaped to the exterior while few or no further eggs were shed from the ovary. The decline continued and produced a minimum in July, when breeding almost completely stopped. A further liberation of eggs from the ovary starting in August led to a second period of larval development from August to November. This was followed by a decline to the winter non-breeding state of the population.

\section{The Clyde Population}

Fig. 4 shows the course of breeding at Farland Point, Cumbrae, during 1952. As in Essex, individuals under $4.0 \mathrm{~mm}$. in size took very little part in breeding, and amongst the Clyde population only a small percentage of the 4-5 $\mathrm{mm}$. group bred. Animals from 5.0 to $7.0 \mathrm{~mm}$. started to breed in April or early May, had one maximum of breeding activity in June, a second in September or October, and then returned to the winter non-breeding state. In the $7+\mathrm{mm}$. group, however, there was no reduction in the percentage of animals breeding in July and August, such as was observed in smaller animals.

\section{Intensity of Breeding}

The mean number of eggs and larvae per breeding individual may be taken as a measure of the intensity of breeding, and Figs. 3 and 4 also show the 
variation in these numbers during 1952 . The rise and fall in breeding intensity coincided with the fluctuations in the percentage of animals breeding, closely in Essex, and approximately in the Clyde.
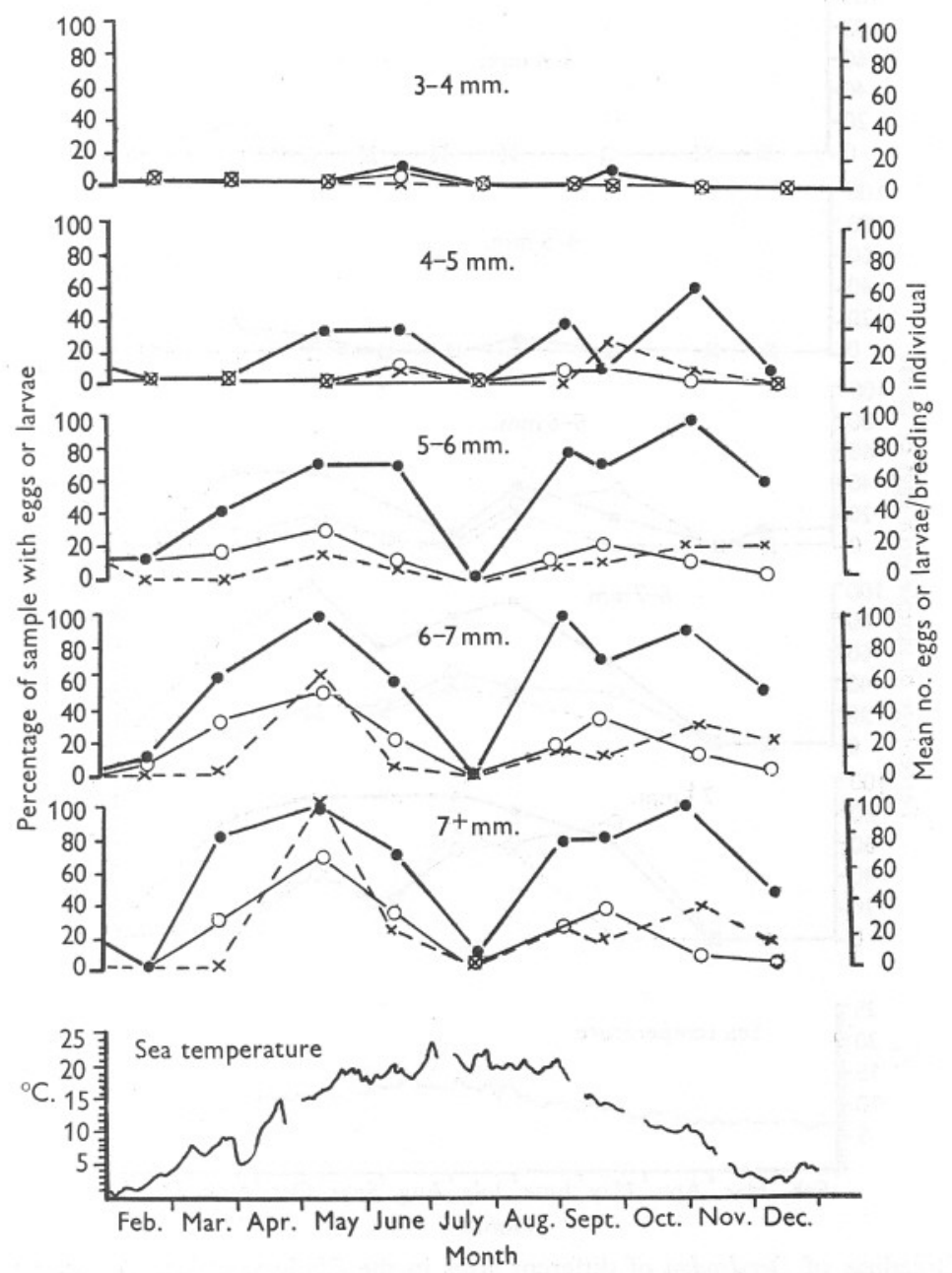

Fig. 3. Breeding of Dendrodoa of different sizes in the Essex samples. - - , percentage with eggs or larvae; $\bigcirc-\bigcirc$, mean number of eggs per breeding individual; $\times-\times$, mean number of larvae per breeding individual.

\section{The Essex Population}

In all animals over about $5.0 \mathrm{~mm}$. long the intensity of breeding in May exceeded that in autumn. The relation between the length of the body and the number of eggs and larvae found in the atrial cavity is shown in Fig. 5. In 
general, breeding started at a body length of between 4.0 and $5.0 \mathrm{~mm}$. and increased in intensity with increasing body length. The greatest number of eggs plus larvae found in any individual was 266 .

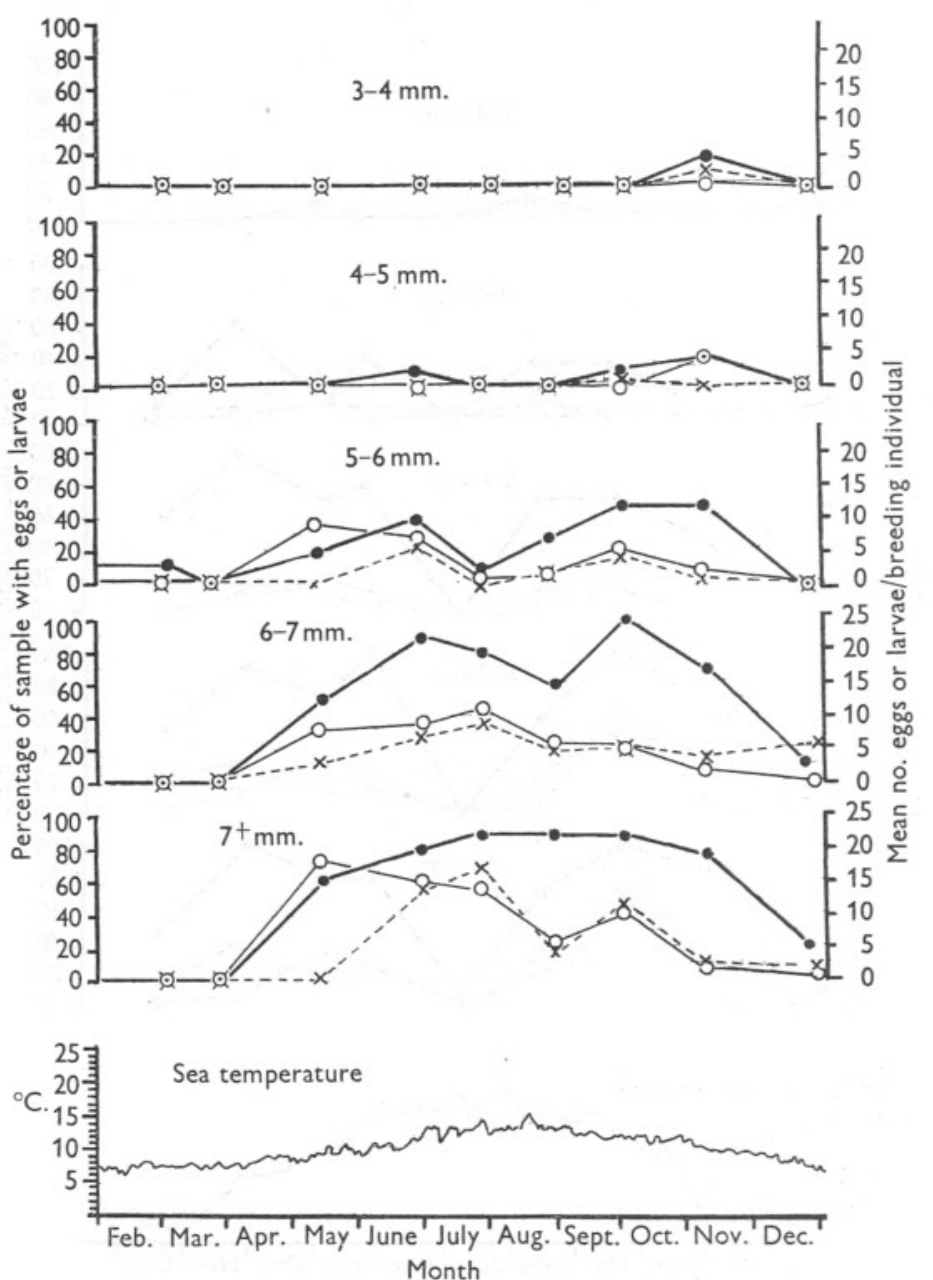

Fig. 4. Breeding of Dendrodoa of different sizes in the Clyde samples. - - percentage with eggs or larvae; $\bigcirc-\bigcirc$, mean number of eggs per breeding individual; $\times-\times$, mean number of larvae per breeding individual.

\section{The Clyde Population}

The first maximum in breeding intensity, in July, was greater than the second maximum, in September or October. It has already been noted that there was a slight depression in breeding activity in summer, observed both in the percentage of breeding individuals and in the breeding intensity, in 
animals of $5.0-7.0 \mathrm{~mm}$. In animals over $7.0 \mathrm{~mm}$. the percentage of breeding individuals remained high throughout the summer, but the intensity of breeding dropped in August, to rise again in September.

Fig. 5 shows the relation between the length of the body and the number of eggs and larvae in the atrial cavity. Very few eggs were produced by animals under $6.0 \mathrm{~mm}$., and in larger animals the number of eggs increased with increasing body length.

The intensity of breeding was much less in the Clyde population than in Essex. The greatest value of the mean number of eggs plus larvae per breeding individual at the height of the reproductive season was only thirty-two in the Clyde, but 172 in Essex, in specimens over $7.0 \mathrm{~mm}$. The greatest number of eggs plus larvae found in any specimen in the Clyde population studied was fifty-five, compared with 266 in Essex. These figures indicate that breeding was about five times more intense in Essex than in the Clyde.
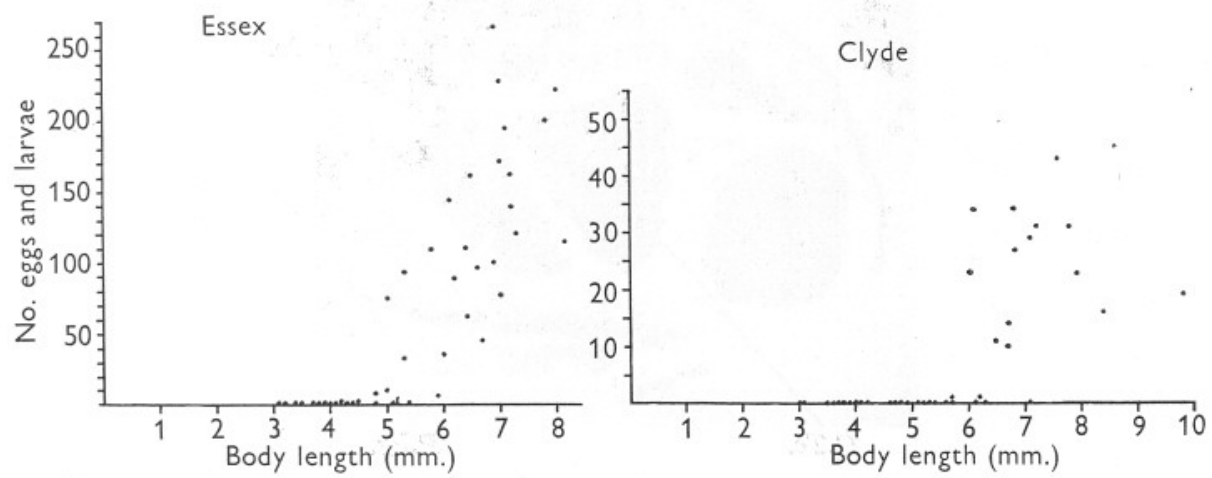

Fig. 5. Relation between length of body and the number of eggs and larvae in the atrial cavity, of specimens from Essex (ro May I952) and the Clyde (26 July I952).

\section{Histological Condition of the Gonad throughout the Year}

In each of the ten samples taken during 1952 the gonads of ten specimens from each of the size groups $5-6,6-7$ and $7+\mathrm{mm}$. were fixed in Bouin, sectioned at I2 $\mu$, stained in Ehrlich's haematoxylin and eosin, and examined. Little variation was found in the condition of gonads from the different size groups and the following account therefore applies in general to all mature animals.

\section{The Essex Population}

In the overwintering condition the testis lobes consisted of a solid central mass of cells with 'resting' nuclei, and a narrow peripheral layer of phagocytes with dark-staining contents (Fig. 6). There were no spermatozoa or spermatids.

The ovarian part of the gonad had germ cells ranging from a small size up to oocytes $60-120 \mu$ in diameter. None of these oocytes had yet acquired yolk. 
There were also present the remains of yolk-laden eggs which had been retained in the ovary at the end of the previous breeding season, and which had been attacked by phagocytes.

The changes which transformed the gonad from this quiescent state to the height of its breeding activity, and the subsequent changes leading again to the overwintering condition, can be best represented graphically (Figs. 7 and 8). During the late winter and early spring the nuclei of the undifferentiated testicular cells started to divide, and by March all specimens had at least some fully developed sperm within the now hollow testis lobes. Meanwhile the peripheral phagocytes had almost completely disappeared from the testis.

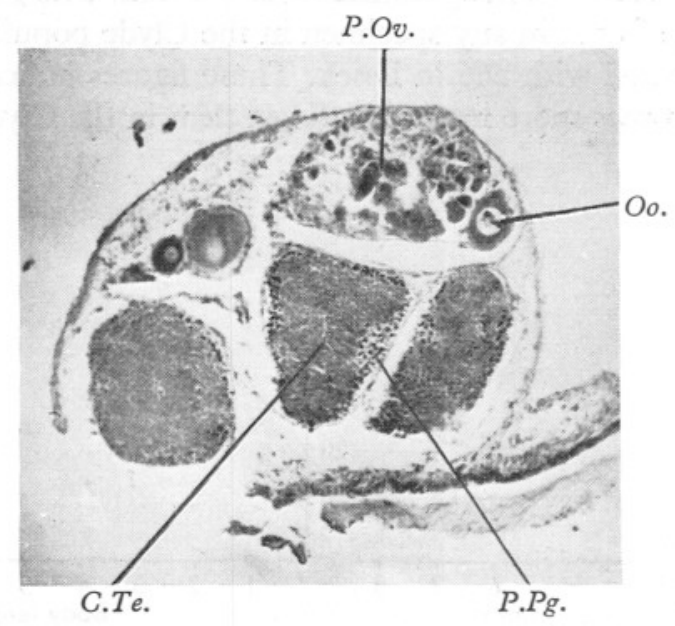

Fig. 6. Photomicrograph of transverse section through gonad in the overwintering condition (Essex, I5 January I952). I2 $\mu$. Ehrlich's haematoxylin and eosin. C.Te., central part of testis lobe; Oo., oocyte; P.Ov., phagocytosed ovum; P.Pg., peripheral phagocytes of testis.

During the period January-March the ovarian part of the gonad had also undergone changes. The remains of the previous year's unshed eggs disappeared by the completion of the process of phagocytosis which had been slowed down or halted in winter. Oocytes increased in size and yolk started to appear in the protoplasm, so that by the end of March all gonads had yolkladen oocytes. In early May the gonad reached its fullest development (Fig. 9).

When spawning was intense, sperm began to disappear from the testis lobes, and at the same time phagocytes started to invade the testis. The number of eggs with yolk fell sharply as a result of ovulation, and residual eggs, together with almost ripe oocytes, were attacked by phagocytes (Fig. 9). Resorption of residual germ cells was rapid in July; phagocytes retired to the periphery of the testis lobes and disappeared, and the remains of unshed eggs were also quickly removed. 
During August and September the gonads were again brought to breeding condition by a series of changes similar to those that occurred in late winter and early spring. After the autumn spawning the gonads were returned to their overwintering condition by the same processes that followed the earlier spawning.

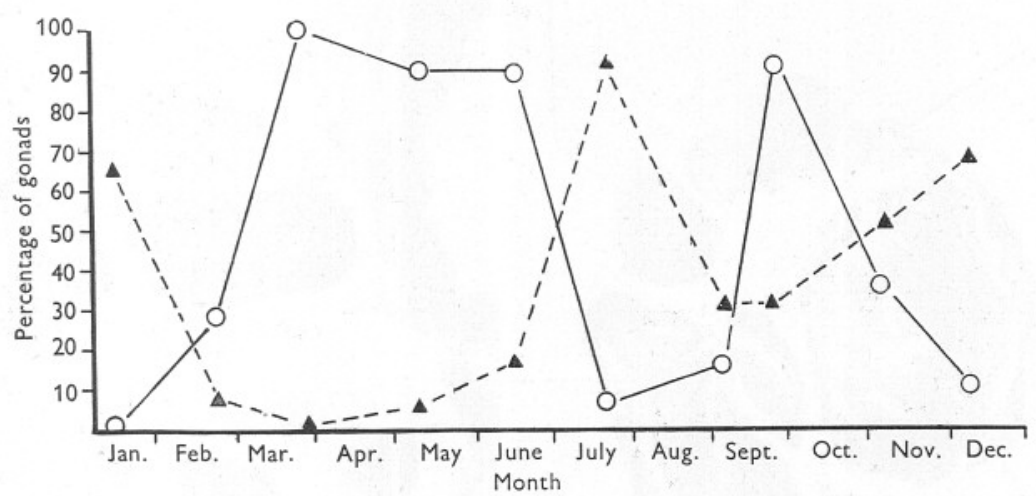

Fig. 7. Histological condition of ovary throughout the year in the Essex samples. Opercentage of gonads with yolk-laden eggs; $\boldsymbol{\Lambda}-\boldsymbol{\Lambda}$, percentage showing phagocytosis of eggs.

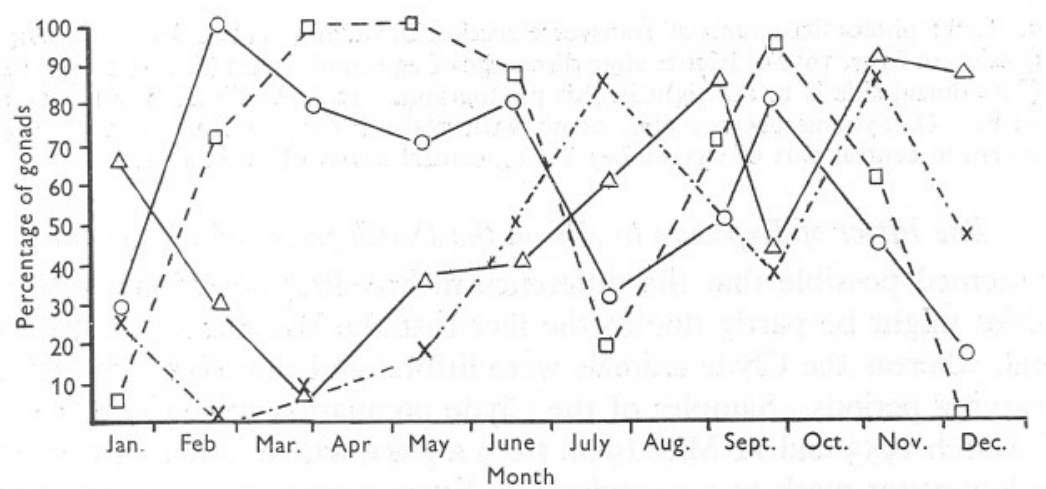

Fig. 8. Histological condition of testis throughout the year in the Essex samples. Opercentage of gonads with dividing male nuclei; $\square---\square$, percentage with sperm; $\triangle-\triangle$, percentage with phagocytes in peripheral part of testis; $x-\times$, percentage with phagocytes in central part of testis.

\section{The Clyde Population}

Figs. Io and I s show the cycle of changes in the gonads of the specimens from Farland Point, Cumbrae. The overwintering condition and the condition at the height of the breeding season were the same in the Clyde as in Essex. But in the Clyde there was relatively little suppression of breeding at any time 
in the summer, and correspondingly little phagocytosis and reversion of the gonad towards a non-breeding state, either in the testicular or ovarian part. The extent of these processes can be seen in the trend of the graphs in August.

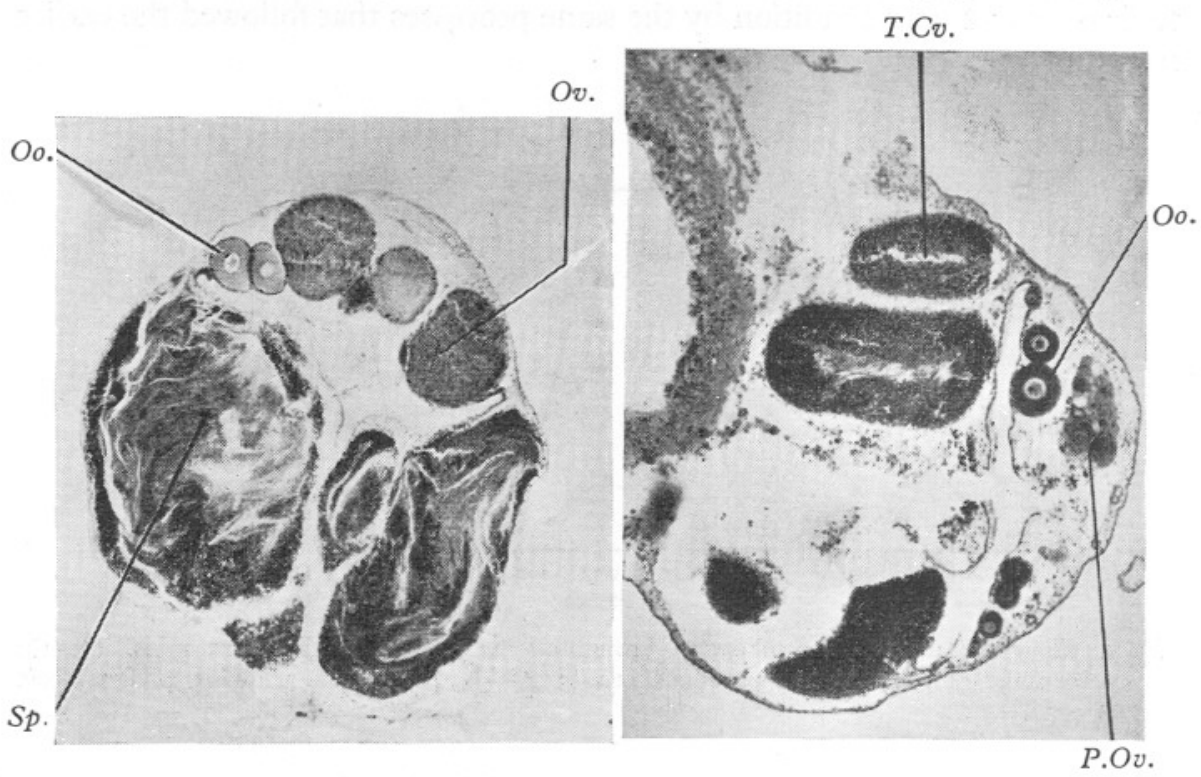

Fig. 9. Left: photomicrograph of transverse section through gonad at fullest development (Essex, Io May, 1952). Right: after discharge of eggs and sperm (Essex, I6 June I952). (The dorsal side is to the right in this photograph.) I2 $\mu$. Ehrlich's haematoxylin and eosin. Oo., young oocyte; Ov., ovum with yolk; P.Ov., phagocytosed ovum; Sp., sperm in central part of testis lobe; T.Cv., central cavity of testis lobe.

\section{The Effect of Exposure to Air on the Development of the Gonad}

It seemed possible that the difference in breeding behaviour in the two localities might be partly due to the fact that the Essex animals were sublittoral, whereas the Clyde animals were littoral and therefore exposed daily for varying periods. Samples of the Clyde population were therefore taken on 6 March I953 and II May 1953, from a place where Dendrodoa extended from low-water mark to a considerable distance up the shore. On each of these dates one sample was taken from the level of Chart Datum $+2 \cdot 2 \mathrm{ft}$. and one from the level of Chart Datum $+7 \cdot \mathrm{I} \mathrm{ft}$. The lower position has a mean exposure of $3.0 \mathrm{hr}$. per day and the upper position $13.7 \mathrm{hr}$. per day. The gonads were sectioned and examined as in the main series of samples, and the results are shown in Table I.

The number of gonads examined (about twenty in each of the four samples) was rather small, but the results leave little doubt that a difference in level of $4.9 \mathrm{ft}$., on the Clyde shore in question, had only a slight effect on the rate of gonad development in spring. It therefore appears likely that the exposure 


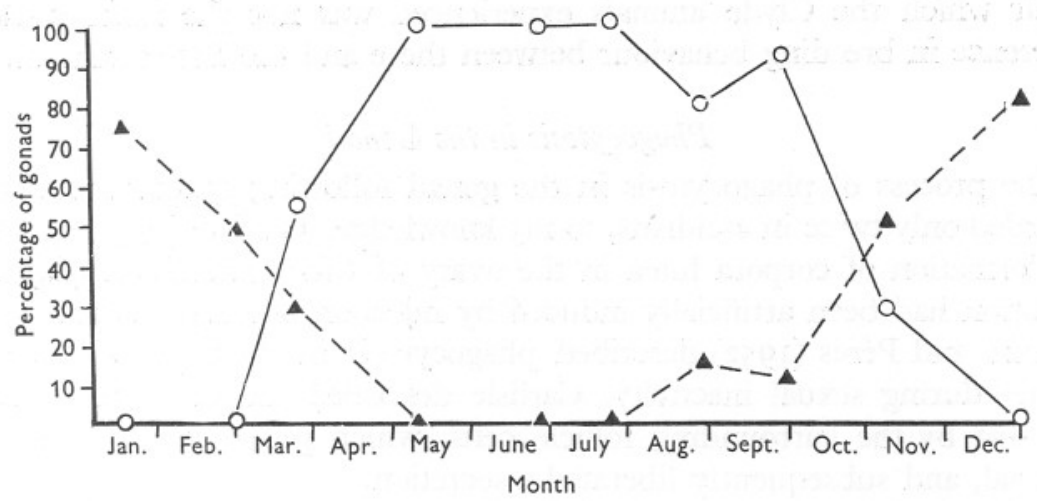

Fig. I0. Histological condition of ovary throughout the year in the Clyde samples. $\mathrm{O}-\mathrm{O}$, percentage of gonads with yolk-laden eggs; $\boldsymbol{\Lambda}-\boldsymbol{\Lambda}$, percentage showing phagocytosis of eggs.

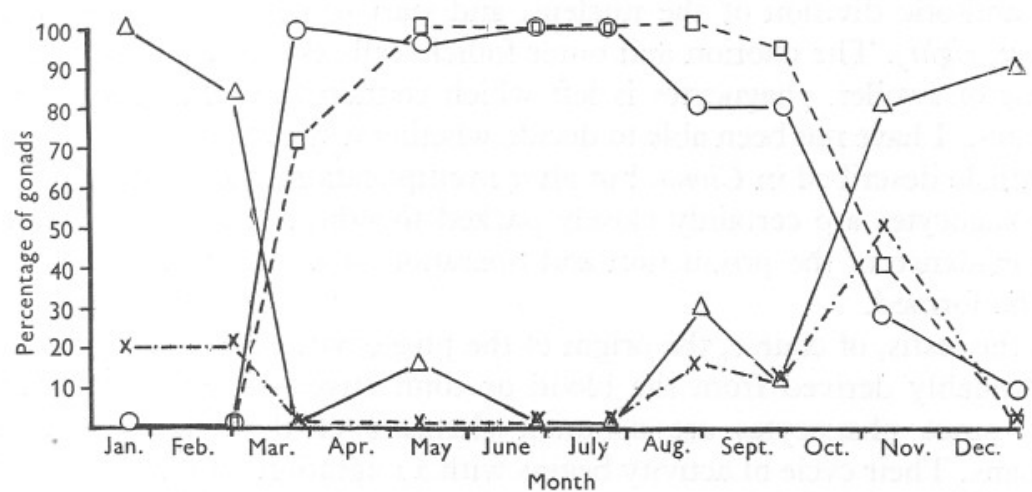

Fig. II. Histological condition of testis throughout the year in the Clyde samples. $\bigcirc-\bigcirc$, percentage of gonads with dividing male nuclei; $\square---\square$, percentage with sperm; $\triangle-\triangle$, percentage with phagocytes in peripheral part of testis; $x-\cdot-\times$, percentage with phagocytes in central part of testis.

Table I. EfFect of Level on the Shore oN

\section{GoNAD DEVELOPMENT}

\begin{tabular}{|c|c|c|c|c|c|c|c|c|}
\hline & & & Perce & ntage of & gonads & ith & & \\
\hline Date & $\begin{array}{c}\text { Level on } \\
\text { shore } \\
\text { (ft. } \\
\text { above } \\
\text { Chart } \\
\text { Datum) }\end{array}$ & $\begin{array}{c}\text { Male } \\
\text { nuclei } \\
\text { dividing }\end{array}$ & Sperm & $\begin{array}{l}\text { Phago- } \\
\text { cytes } \\
\text { in } \\
\text { central } \\
\text { testis }\end{array}$ & $\begin{array}{l}\text { Phago- } \\
\text { cytes } \\
\text { in } \\
\text { peri- } \\
\text { pheral } \\
\text { testis }\end{array}$ & $\begin{array}{l}\text { Yolk } \\
\text { in } \\
\text { eggs }\end{array}$ & $\begin{array}{l}\text { Phago- } \\
\text { cytosis } \\
\text { of } \\
\text { eggs }\end{array}$ & $\begin{array}{c}\text { Diameter } \\
\text { of largest } \\
\text { oocytes } \\
(\mu)\end{array}$ \\
\hline 6 March I953 & $\begin{array}{l}2 \cdot 2 \\
7 \cdot 1\end{array}$ & $\begin{array}{r}100 \\
91\end{array}$ & $\begin{array}{l}58 \\
50\end{array}$ & $\begin{array}{r}\text { I0 } \\
7\end{array}$ & $\begin{array}{r}2 \\
2 \mathrm{I}\end{array}$ & $\begin{array}{l}30 \\
22\end{array}$ & $\begin{array}{l}15 \\
30\end{array}$ & $\begin{array}{l}135 \\
\text { I } 26\end{array}$ \\
\hline II May I953 & $\begin{array}{l}2 \cdot 2 \\
7 \cdot 1\end{array}$ & $\begin{array}{l}\text { IOO } \\
\text { I0O }\end{array}$ & $\begin{array}{l}\text { IOO } \\
\text { IOO }\end{array}$ & $\begin{array}{l}0 \\
0\end{array}$ & $\begin{array}{l}0 \\
0\end{array}$ & $\begin{array}{r}100 \\
96\end{array}$ & $\begin{array}{l}0 \\
0\end{array}$ & $\begin{array}{l}279 \\
287\end{array}$ \\
\hline
\end{tabular}


to air which the Clyde animals experienced was not the main cause of difference in breeding behaviour between these and the Essex animals.

\section{Phagocytosis in the Gonad}

The process of phagocytosis in the gonad following spawning has been recorded only twice in ascidians, to my knowledge. Carlisle (I95I) observed the formation of corpora lutea in the ovary of Ciona intestinalis (L.) after ovulation had been artificially induced by injection of mammalian gonadotrophin, and Pérès (1952) described phagocytosis in the testis of the same species during sexual inactivity. Carlisle described the invasion of nearly ripe ova by the surrounding follicle cells, which phagocytosed the yolky material, and subsequently liberated a secretion.

In Dendrodoa grossularia essentially the same process occurs after natural ovulation. The inner follicle cells, which lie in the protoplasm of the ovum immediately internal to the chorion, migrate inwards, multiply apparently with amitotic division of the nucleus, and start to ingest the yolk granules (Fig. 9, right). The chorion and outer follicle cells eventually disappear, and a mass of swollen phagocytes is left which contain the remains of the yolk granules. I have not been able to decide whether a syncytium is formed, such as Carlisle described in Ciona, but after multiplication, and ingestion of yolk, the phagocytes are certainly closely packed together. Nor have I seen any clear evidence of the production and liberation of a secretion, although this may be formed.

In the testis, of course, the origin of the phagocytic cells is different. They are probably derived from the blood or connective tissue surrounding the testis, since phagocytes are common elements of these tissues in many ascidians. Their cycle of activity begins with a migration into the tissue of the testis. When they have penetrated to the central part of the lobes where residual sperm are situated, they ingest these sperm and perhaps also spermatids. They then withdraw with their contents to the peripheral part of the testis lobes and eventually disappear, perhaps by moving out of the testis altogether although this was not discovered.

How far the processes involving phagocytosis in the ovary and testis can be regarded as comparable depends on whether the function of the phagocytes in the ovary is primarily to remove unshed eggs, or whether this removal is merely a necessary step towards the production of a secretion. In the testis it appears that no more is involved than the removal of unshed germ cells. Also the origin of the phagocytic cells is different in the two cases. The question cannot be answered until we know something about the nature of the supposed secretion formed in the ovarian part of the gonad.

\section{Factors influencing Breeding}

Temperature is probably the most important of the factors influencing the breeding of marine invertebrates. In many species there is no fixed 
temperature at which spawning occurs, but rather, as Korringa (I94I) says of Ostrea edulis L., 'the maturation-period of the eggs is a function of time and temperature'. This has been shown to be true, for instance, in Crassostrea virginica (Loosanoff \& Davis, 1952). Nevertheless, these workers also found that a certain minimum temperature is required before maturation of the gonad can start. Very little is known of the precise effect of other factors, e.g. food, in initiating the reproductive cycle. Once the gametes are mature they may be liberated in different species by a variety of stimuli, of which temperature change is one of the commonest.

When considering the influence of temperature on the breeding of Dendrodoa grossularia we must first recognize that the Clyde animals studied, being intertidal in habitat, were subjected to air temperature for varying daily periods. The effect of air temperature on the animals during their period of exposure is unknown. It seems likely, however, to have been much less than the effect of water temperature during submersion, since some of the most important vital activities, e.g. water filtering and feeding, cease during exposure to the air. The evidence from samples taken from points high and low on the shore also suggests that exposure to air was not a major factor affecting the rate of gonad development. It is perhaps reasonable, therefore, to consider only water temperature when dealing with the Clyde animals. Yet it is difficult to find any correlation between the sea-surface temperature and the onset of those changes in the gonad which initiated the breeding cycle. Thus although the water temperature in March was relatively steady between $7 \cdot 0$ and $7.5^{\circ} \mathrm{C}$., it was during this period that important and rapid changes were accomplished in both male and female parts of the gonad (Figs. IO, II). Similar changes in the gonads of the Essex animals had occurred at least a month before (Figs. 7, 8), during a time when the water temperature there rose quickly from 0.0 to $3.5^{\circ} \mathrm{C}$. Unless we assume the existence of physiologically differentiated races in the two localities, adapted to different temperature ranges, we must conclude that it was not temperature level which determined the onset of those changes in the gonad. Nor was it a rising temperature that started the maturation of the gonad in the Clyde animals, although this could explain the results obtained in the Essex samples.

The first liberations of ripe gametes from the gonads occurred in spring at about the same water temperature, 8.0-9.0 C., in the Essex and Clyde animals. At the approach of winter the liberation of gametes from the gonads ceased when the temperature dropped to about II. $0^{\circ} \mathrm{C}$., in both areas.

It is more difficult to discover whether there also exists an upper temperature limit to the liberation of gametes. The answer to this question depends on the explanation adopted for the absence of breeding during July in Essex and the reduced breeding in July and August in the Clyde. Two possible explanations can be considered. The first is that intense spawning in early summer exhausted the animals in Essex so that by July they were spent. If this explanation were right the Clyde animals, having bred with much less 
intensity, should still have been capable of undiminished breeding thoughout the summer. But in fact there was a definite reduction of breeding in July and August, and the theory of exhaustion is therefore unsatisfactory.

The second possible explanation is that, in addition to the lower temperature limit which has been demonstrated, an upper temperature limit to the liberation of gametes from the gonad also exists. Histological examination shows that in July the gonads of the Essex animals still had large yolky eggs but these, instead of being shed, were retained and attacked by phagocytes, a process suggesting that an environmental factor suppressed further ovulation. That factor may well have been high temperature.

It appears that, at temperatures over $15.0^{\circ} \mathrm{C}$, , ovulation becomes progressively less, and above about $20.0^{\circ} \mathrm{C}$. is totally suppressed.

The present investigation has raised a number of problems concerning the influence of environmental factors on breeding which can probably only be solved by experiment.

\section{SUMMARY}

Samples of the ascidian Dendrodoa grossularia were studied from a sublittoral habitat in the River Crouch, Essex, and from a littoral habitat on the Isle of Cumbrae, Firth of Clyde. The pattern of annual growth was similar in these areas, and the life-span appeared to be I8 months to 2 years.

Developing eggs are retained in the atrial cavity by brood filaments.

In Essex a first maximum of breeding in spring and early summer was separated from a second maximum in late summer and autumn by a short interval when no breeding occurred. In the Clyde breeding was continuous from early summer to autumn, but was slightly reduced in August.

The histological changes in the gonad are described. Phagocytosis in both ovary and testis followed each period of breeding.

Gametes were shed from the gonad when the sea temperature in spring reached $8 \cdot 0-9 \cdot 0^{\circ} \mathrm{C}$., and ceased to be shed in autumn when the sea temperature fell below about $\mathrm{II} \cdot 0^{\circ} \mathrm{C}$. Release of gametes appeared to be reduced at temperatures above $15.0^{\circ} \mathrm{C}$. and totally suppressed above about $20.0^{\circ} \mathrm{C}$.

\section{REFERENCES}

CARLISLE, D. B., I95I. Corpora lutea in an ascidian, Ciona intestinalis. Quart. F. micr. Sci., Vol. 92, 2, pp. 20I-3.

KORRINGA, P., I94I. Experiments and observations on swarming, pelagic life and setting in the European flat oyster Ostrea edulis L. Arch. néerl. Zool., T.5, pp.I-249.

LoosANOFF, V. L. \& DAVIS, H. C., I952. Temperature requirements for maturation of gonads of northern oysters. Biol. Bull., Wood's Hole, Vol. 103, pp. 80-96.

MILlAR, R. H., I952. The annual growth and reproductive cycle in four ascidians. F. Mar. biol. Ass. U.K., Vol. 31, pp. 4I-6I.

PÉRÈS, J. M., 1952. Recherches sur le cycle sexuel de Ciona intestinalis (L.). Archiv. Anat. micr. Morph. exp., T. 4I, pp. I53-83. 